\title{
Measurement of sodium in heart failure
}

Hyponatremia is common in adults with heart failure. Recently, Price JF et al. [1] determined sodium level in 141 children with decompensated heart failure. In these children, hyponatremia $(<135 \mathrm{mmol} / \mathrm{L})$ was found to be common and independently associated with the composite end point of in-hospital death, cardiac transplantation and need for mechanical circulatory support.

The authors of the interesting report failed to state the method utilized for sodium testing. This electrolyte is nowadays measured using either direct, which is utilized in point-of-care analyzers, or indirect potentiometry, used in clinical laboratories [2]. The two methods generally show good agreement as long as serum protein and lipid concentrations remain normal. Direct potentiometry is unaffected by changes in protein and lipid levels but indirect potentiometry is affected. Reduced serum protein, which is a common feature of heart failure, causes spuriously high sodium levels: for each 10 g/L fall in total protein, there is a rise in sodium level of nearly $1 \mathrm{mmol} / \mathrm{L}$ [2] .

In conclusion, in heart failure, which usually goes along with a low circulating protein level [3], direct potentiometry is the technique of choice for sodium determination because of its ability to avoid underestimation of hyponatremia.

Gregorio P. Milani, MD, Milano, Italy

Emilio F. Fossali, MD, Milano, Italy

Mario G. Bianchetti, MD, Bellinzona, Switzerland

Sebastiano A. G. Lava, MD MSc, Bern, Switzerland

Gregorio P. Milani, Fondazione IRCCS, Ca' Granda, Ospedale Maggiore Policlinico, Via della Commenda 9, 20122 Milan, Italy; Phone: +393498320575; Fax: +39(0)255032819. Email: milani.gregoriop@gmail.com 


\section{References}

1. Price JF, Kantor PF, Shaddy RE, Rossano JW, Goldberg JF, Hagan J, Humlicek TJ, Cabrera AG, Jeewa A, Denfield SW, Dreyer WJ, Akcan-Arikan A. Incidence, severity, and association with adverse outcome of hyponatremia in children hospitalized with heart failure. Am J Cardiol 2016;118:1006-1010.

2. Goldwasser P, Ayoub I, Barth RH. Pseudohypernatremia and pseudohyponatremia: a linear correction. Nephrol Dial Transplant 2015;30:252257 .

3. Arques S, Ambrosi P. Human serum albumin in the clinical syndrome of heart failure. J Card Fail 2011;17:451-458. 